\title{
Explaining the Voluntary Compliance to COVID-19 Measures: An Extrapolation on the Gender Perspective
}

\author{
Widya Paramita $^{1,2} \cdot$ Rokhima Rostiani $^{1,3}\left(\mathbb{D} \cdot\right.$ Sari Winahjoe $^{1} \cdot$ Amin Wibowo $^{1}(\mathbb{C}) \cdot$ Risa Virgosita $^{1} \cdot$ Handini Audita $^{1,2}$
}

Received: 12 September 2020/Accepted: 27 January 2021/Published online: 4 March 2021

(C) Global Institute of Flexible Systems Management 2021

\begin{abstract}
The discourse of gender amidst the COVID-19 pandemic had been a big fuss. Amongst the discussions is the gender-related responses to COVID-19 that generally assume females to better respond to COVID-19 than males. Despite the converging assumptions, previous studies tend to conceptualize gender as binary biological sex, and consequently, there is little understanding of the genderCOVID-19 measures compliance relationship. By taking gender as a multidimensional perspective, this research aims to examine the relationship between sex, gender psychology, and gender-role with voluntary compliance to COVID-19 measures as well as the moderating role of situational aspects that can activate individuals' responses toward COVID-19. A survey had been conducted in Indonesia, as Indonesia represents a country with relaxed
\end{abstract}

Rokhima Rostiani

rokhima@ugm.ac.id

Widya Paramita

widyaparamita@ugm.ac.id

Sari Winahjoe

sariwinahjoe@ugm.ac.id

Amin Wibowo

aminwibowo@ugm.ac.id

Risa Virgosita

risa.virgosita@ugm.ac.id

Handini Audita

audita@ugm.ac.id

1 Department of Management, Faculty of Economics and Business, Universitas Gadjah Mada, Yogyakarta, Indonesia

2 LPDP Scholarship Awardee, Ministry of Finance, Republic of Indonesia, Jakarta, Indonesia

3 Recipient of BPPDN 2019 Scholarship, Ministry of Higher Education, Republic of Indonesia, Jakarta, Indonesia
COVID-19 restrictions making voluntary compliance is deemed important. Consistent with our predictions and previous studies, females tend to better comply with COVID-19 when gender is treated as dichotomous sex. However, a closer look at the gender dimensions revealed that gender psychology (feminine vs masculine) and gender-role (traditional vs egalitarian) provide a better explanation of the specific compliance behaviour toward COVID-19 measures. Interestingly, although situational pathogen avoidance (SPA) directly leads to adherence to several compliance behaviours, it does not moderate the four compliance behaviour of COVID-19 measures. Theoretical and practical contributions are further discussed.

Keywords COVID-19 · Gender psychology ·

Gender-role $\cdot$ Sex $\cdot$ Situational pathogen avoidance (SPA) Voluntary compliance

\section{Introduction}

The discourse about gender is amongst other discourses that get heated amidst the COVID-19 pandemic (Maclean 2020; Wittenberg-Cox 2020). The primary issue addressed in prior scholar discussion is related to country performance to address the COVID-19 pandemic as countries with female leaders are seen to be excellent in suppressing the spread of the deadly virus (Champoux-Paille and Croteau 2020). These countries are New Zealand with Jacinda Ardern, Norway with Erna Solberg, and Taiwan with Tsai Ing-wen that had been successful in managing the COVID-19 pandemic in their countries (WittenbergCox 2020). Moreover, the success of female country leaders was attributable to the feminine qualities that they infused to the leadership and political culture that 
subsequently brought substantial differences in addressing COVID-19 pandemic (Maclean 2020; Wittenberg-Cox 2020; Taub 2020). Furthermore, there are association between effective leadership and femininity-linked characteristics that supports the success of female leadership in crisis management (Gartzia et al. 2012). The feminine qualities include empathy, love, compassion, collaboration, as opposed to aggressiveness, domination, and competitiveness that have been strongly associated with masculine characteristics of male country leaders (Maclean 2020; Taub 2020).

Consistently, existing studies that examine the gender effects on individual response toward COVID-19 tend to conclude that females are more likely to take COVID-19 seriously and hence, are more likely to comply with COVID-19 measures even when they are not mandatory in their countries (Capraro and Barcelo 2020; Galasso et al. 2020; Haischer et al. 2020). For instance, a study by Clark et al. (2020) had shown that females are more likely to comply with COVID-19 measures, such as wearing a mask, social distancing, handwashing, and staying at home, compared to males. Likewise, another study by Brouard et al. (2020) revealed that females abide by COVID-19 public health measures.

Understanding the gender role in response to COVID-19 measure is important as previous studies have concluded that behaviour is gendered and marketers-in this case social marketers- have been long facilitating inidividual's self-expression need by associating specific behaviour or object with gender characteristics (Pinna 2020; Neale et al. 2016). Such that, individuals are expected to prefer behaviour or object that are consistent with their self-concept (e.g. femininity or masculinity) (Pinna 2020). Consequently and in addition to the theoretical contributions, understanding gender differences in response toward COVID-19 measures will help marketers to embrace the dynamics of reality (Sushil 1997; Ganuthula and Sinha 2019; Evans and Bahrami 2020) and design an innovative approach (i.e. gendered social marketing campaign) to manage the COVID-19 pandemic, particularly via social marketing approach.

Despite the converging results amongst the existing studies, a closer look at the literature highlights several important research gaps. First, research that examines gender and COVID-19 compliance generally treated gender as dichotomous (i.e. female vs male) without considering the social and psychological components as a complex construct (Bitan et al. 2020; Brouard et al. 2020; Clark et al. 2020). In particular, the literature suggests that gender is not a simple biological difference but a matrix of information that is continuously being shaped and changed by the environment and technology (Skitka and Maslach 1990; Rougharden 2003). For instance, the gender-role attitude has been changing over years from the traditional mutually exclusive roles to the more egalitarian roles between females and males that subsequently influence their attitudes and behaviours (McCabe et al. 2006; Lee and Lee 2018). It is more common now for males to perform caring duty or other behaviours that are related to feminine traits (Lee and Lee 2018).

Also, although in general females are associated with feminine traits whereas males are associated with masculine traits, the literature suggests that the degree of femininity and masculinity may differ across females and males (Skitka and Maslach 1990; Yang and Merrill 2017). Moreover, previous studies also revealed that masculinity and femininity present across gender (Lee and Lee 2018; Guillet et al. 2019). In sum, gender-role and psychological gender better explain individuals' attitudinal and behavioral responses than sex (McCabe et al. 2006). As previous studies were restricted to the dichotomous gender difference and discounted the gender-role and gender psychology, it is likely that the existing research does not capture the gender-COVID-19 responses phenomena accurately.

Second, despite the convergent conclusions on the relationship between gender and responses toward COVID19 across studies (Capraro and Barcelo 2020; Galasso et al. 2020; Haischer et al. 2020), existing studies have neglected the situational aspects that may influence individuals' responses to COVID-19 measures. Such that, when the situational aspects that can activate individuals' motivation to avoid catching COVID-19 are salient, people are more likely to comply with the COVID-19 measures (McConnell 2011; Neuberg et al. 2011; Paul and Chowdhury 2020). Previous research has demonstrated that viewing slideshows about others who are sick, reading an article about the threat of an infectious disease, skimming article that uses disease metaphors, and recalling and verbally describing a time they felt afraid of illness, can activate people's motivation to avoid diseases (Lund and Miller 2014; Makhanova et al. 2015; Brown et al. 2019). In sum, although there is personality or individual difference in their general response to disease, situational factors may strengthen or weaken their actual responses (Makhanova et al. 2020). Furthermore, understanding situational aspects that can promote voluntary compliance to COVID-19 measures will help social marketers and policymakers to design an effective campaign or policy.

Accordingly, this research aims to understand individuals' voluntary compliance with COVID-19 measures by taking a multidimensional perspective of gender. In particular, we represent gender as biological sex, gender-role, and psychological gender as suggested by gender identity theory (Edwards and Spence 1987; Vantieghem et al. 2014). By considering gender as a multidimensional 
construct, we expect to answer key questions: what gender aspects that influence individual compliance to COVID-19 measures: is it the biological aspect, psychological gender, or gender role? Does feminine characteristic of females promote compliance to COVID-19 measure as assumed by previous studies? To extend the understanding and the practical contribution of the study, we also propose the moderating role of situational pathogen avoidance (SPA). SPA is conceptualized as individual differences in pathogen avoidance that are expressed through proximate psychological states that are affected by people's current environment (Makhanova et al. 2020). Taken together, we propose that gender as a multidimensional construct (i.e., sex, gender-role, and psychological gender) influences voluntary compliance with COVID-19 measures and the effect is moderated by situational pathogen avoidance (SPA).

In the subsequent section of theoretical framework, we will elaborate gender identity theory, situational pathogen avoidance (SPA), and compliance with COVID-19 measures, as can be seen in Fig. 1 and hypotheses development. Furthermore, we will explain the research method followed by the results, general discussion, theoretical and practical contributions as well as limitations and future research.

\section{Theoretical Development}

\section{Gender Identity Theory}

Understanding the difference between sex and gender has long been a debatable issue between nature and nurture concept in psychology (Meier-Pesti and Penz 2008). Sex conceptually defines as innate structural and physiological characteristics, whereas gender represents all the complex attributes that a culture ascribes to each of the sexes (Deaux 1985; Lott and Maluso 2002). Historically, gender differences in cognitive and emotional responses are attributable to biological sex differences (Brebner 2003; Hyde 2016). For example, males perform better on math and spatial tasks, while females perform better on verbal tasks (Deaux 1985). However, a recent study indicated that males and females perform similarly on math and spatial tasks, moreover the females' ability to perform spatial tasks match to males' ability after they received appropriate training (Hyde 2016). Also, a study by Davis (1995) revealed that females and males differences in emotion regulation is attributable to motivation rather than ability. Such that, when males are motivated to regulate their emotions, they are also able to do so (Davis 1995; Timmers et al. 1998).

The differences between females and males are not merely associated with biological sex difference but also the social aspects that are incorporated in their gender schema that tell them what is considered appropriate and expected for females and males in a particular society (Crane and Markus 1982; Levy and Carter 1989). Consistently, researchers argue that both sex and gender are not mutually exclusive, they interact with each other to influence any differences between females and males (Deaux 1985; Meier-Pesti and Penz 2008). Accordingly, gender identity theory evolved as an alternative to the dichotomous classification of gender-based on biological sex. It proposes that gender phenomena are multifactorial, consisting of biological sex, instrumental, and expressive psychological traits that are often known as psychological gender, as well as gender-role attitudes (Spence 1985; Deaux 1985).

Psychological gender refers to the masculine (instrumental) and feminine (expressive) traits associated with females and males that are consistent with the socially endorsed desirable traits for females and males (McCabe et al. 2006; Mehta and Strough 2010). In other words, psychological gender represents predispositions or capacities that have considerable trans-situational significance influence on behaviours (Spence 1985). Feminine traits, such as expressive and communal traits are characterized

Fig. 1 Research framework

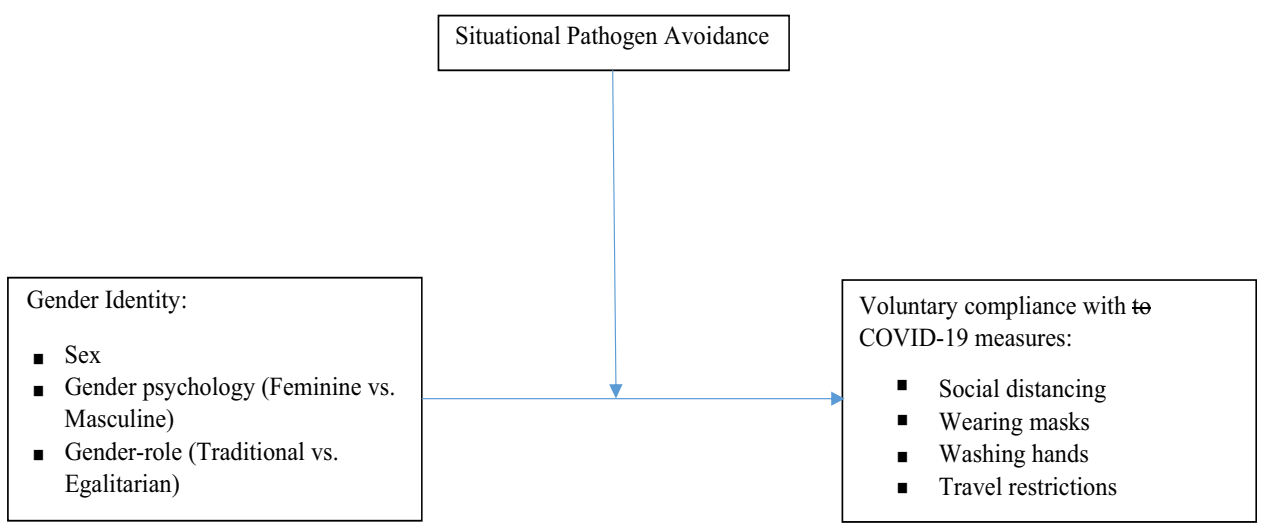


by caring for well-being, whereas masculine traits, including agentic and instrumental traits, are described as 'getting the job done' or 'cognitive focus' (Mehta and Strough 2010; Mehta and Dementieva 2017). Although masculinity and femininity seem to be bipolar, recent studies found a masculine-feminine characteristic found amongst females and males (Niedlich et al. 2015; Kachel et al. 2016). Moreover, females and males exhibit different extent of masculinity and femininity regardless of their biological sex (Leszczynski and Strough 2008; Mehta and Dementieva 2017). Also, the literature suggests that the degree of masculinity and femininity amongst females and males is unstable over time and across contexts (Twenge 1999; Mehta and Dementieva 2017). Males and females are more likely to report more masculine traits when they are surrounded by males and vice versa (Mehta and Dementieva 2017). From a longitudinal perspective, gender differences in masculine and feminine traits decreased after the second women's movement (Strough et al. 2007).

Gender-role attitudes represent individuals' beliefs about which roles are appropriate for women and men that range from egalitarian to traditional (McCabe et al. 2006). More traditional gender-role attitudes believe that different, mutually exclusive roles are appropriate and socially acceptable for men and women (Skitka and Maslach 1990; McCabe et al. 2006). For instance, within a traditional gender-role, females are expected to nurture and care for the children, while males are expected to take employment outside the home (Blackstone 2003). However, there have been significant changes in the number of fathers who are the primary caregivers of their children. The changes are accompanied by the shifting beliefs that males should not dominate females in the relationship, should value positive emotions, affective, relational, emotional and interdependent qualities, as well as redefine the role concept of traditional gender-roles (Elliot 2016; Lee and Lee 2018). Such that, being responsible men is not about providing financing for the families but can also be defined as taking care of the children (Elliot 2016). As gender-roles are integrating across gender, we expect that the values and beliefs associated with a particular role should not be determined by the sex types (McCabe et al. 2006).

\section{Gender and Voluntary Compliance with COVID-19 Measures}

According to World Health Organization (WHO), there are several measures of COVID-19 to protect self and others as well as to prevent the spread of coronavirus, such as: practicing social distancing, wearing masks, regularly washing hands, and restricting travel especially with public transports, amongst others (World Health Organization 2020). Literature, in general, suggests that gender is an important social determinant of health and health behaviour (Courtenay 2000; Fleming and Agnew-Brune 2015). For instance, feminine characteristics are strongly associated with health behaviour such as cleanliness, food preparation, family health, laundry, and domestic maintenance (Galdas et al. 2010; Brough et al. 2016). As the association between femininity and health is strong, it will influence social judgement and self-perception so that people who engage in healthy behaviour are perceived to be more feminine (Brough et al. 2016; Swim et al. 2020). More importantly, femininity is often associated with weakness, fragility, and susceptibility to illness, whereas masculinity is associated with robustness, fortitude, and invulnerability (Courtenay 2000). Accordingly, previous studies demonstrated that females tend to be motivated to take care of their health.

In contrast, males tend to perform behaviours that are detrimental to their health such as smoking and not using sunscreen to affirm their masculinity (Hart et al. 2019; Springer and Mouzon 2019). Consistently, people who perceive themselves to be masculine might be discouraged from performing healthy behaviours (Brough et al. 2016). However, males who adopt a more egalitarian gender-role who believe that gender-roles are equal for both females and males, are more likely to adopt healthy behaviours as they are more involved in activities of caring the family than males who adopt more traditional gender-roles (McCabe et al. 2006; Lee and Lee 2018). As health promoting behaviour is generally perceived as positive behaviours, it is easier for males with egalitarian gender role perspective to enact their healthy behaviours (Hart et al. 2019). Thus, we propose that males with egalitarian gender role are more likely to wash their hands to prevent COVID19 spread.

Similarly, females who adopt a more egalitarian gender role may expect less obligation of caring for others (but more concern to themselves) (Annandale and Hunt 1990). Thus, females with egalitarian gender role might have different motivation for healthy behaviour (i.e. to maintain self-health rather than for community protection) (Annandale and Hunt 1990; Hart et al. 2019). Thus, we propose that the higher the femininity, the more likely males and females to wash hands and the higher the masculinity, the less likely males and females to wash hands. Also, genderrole is positively related to healthy behaviour, particularly washing hands for males, while the effect is insignificant for females. Formally, we hypothesize:

$\mathbf{H}_{\mathbf{1}}$ Females and males are more (less) likely to wash hands when they have feminine (masculine) characteristics. 
$\mathbf{H}_{2}$ Males are more likely to wash hands when they subscribe to the egalitarian gender-role, while the effect of gender-role for females are insignificant.

Subsequently, literature also suggests that femininity is strongly related to the tendency to maintaining a relationship (Mehta and Strough 2010; Drydakis et al. 2018), while masculinity is associated with independency and agentic characteristic (Mehta and Strough 2010). Consistently, several studies demonstrated that feminine individuals care about maintaining interpersonal relationship more than males (Yang and Grigus 2019), more interested in vocational activities that involve interacting with others $(\mathrm{Su}$ et al. 2009), more cooperative in large groups (Bailliet et al. 2011), and more likely to experience intimacy in relationships compared to males (Fletcher and Kerr 2010). Furthermore, the literature suggests that as feminine individuals are more relationship-oriented than males, they invest more on their social relationships and hence have higher expectations on their relationship that make them more vulnerable to loneliness where the expectations cannot be met and when the social relationships are absence (Maes et al. 2015, 2019). Thus, we propose that the higher the femininity, the less likely females to comply with social distancing measures, while the higher the masculinity, the more likely females to comply with social distancing measures.

The formal hypothesis is:

$\mathbf{H}_{3}$ Females and males are more (less) likely to comply with social distancing measures when they have masculine (feminine) characteristics.

There have been several studies that link gender and wearing mask (Haischer et al. 2020; Rader et al. 2020). Generally, the results suggest that females are more likely to wear masks to prevent COVID-19 spread, however it is not clear what psychological mechanism that explain the results. On the contrary, popular literature has been flooded with articles discussing the implication of wearing masks on facial makeup (Hadden 2020; Ruffner 2020; Tan 2020). Such that, those articles revealed the need for females to adapt to wear masks with their make-up routine and also the mask-induced skin problems such as acne (Hadden 2020; Tan 2020). For instance, an article by Vogue provides guidelines for skincare and makeup to adapt to the new normality of wearing masks by avoiding foundations and be more expressive with the eyes (Ruffner 2020).

Likewise, academic literature has recorded the importance of make up for female individuals, as females tend to associate makeup with beauty and well-being while males consider makeup as significantly contributes to females' charm and beauty (Loegel et al. 2017). Even more, attractive individuals are assumed to have better personalities, greater abilities, and higher moral standards, and makeup is known to improve appeal and attractiveness for females (Klatt et al. 2016; Kret 2016). More importantly, makeup has been considered as a social norm for feminine females (Kret 2016; Loegel et al. 2017).

Notably, make up and skin care are no longer limited for females with feminine characteristics but also male with feminine characteristics (Kim et al. 2013). Such that, in East Asian countries (i.e. South Korea) males gained more concerned about their facial appearance and involved more in make-up and skin care routines known as KKot Minam, literally means 'flower handsome males', that became more accepted across nations in Asia through the popularity of Korean Pop worldwide (Kim et al. 2013; Miyose and Engstrom 2015). Taken together, wearing masks may be costly for females and males with feminine characteristics. Consequently, we propose that females with feminine characteristics are less likely to comply with wearing masks measures. In contrast, females with masculinity characteristics are more likely to comply with wearing masks measures.

$\mathbf{H}_{4}$ Females and males are more (less) likely to wear a mask when they have masculine (feminine) characteristics.

In terms of travelling, gender differences in their travelling pattern are well documented in previous researches. For example, females tend to travel a shorter distance, have complex trip-chains, rely more on slower modes such as walking and buses and make a more significant number of trips (Turner and Neimeier 1997; Lee et al. 2007). Those travel pattern differences were attributable to the genderrole in society in which females are more likely to have spatially constrained opportunities to paid employment and more likely to have local part-time work (Lyons et al. 2002; McQuaid and Chen 2012). Also, it is due to females tendency to perform multiple roles as workers and carers of children that prohibit them to travel farther (Turner and Neimeier 1997; Tilley and Houston 2016).

However, there is strong evidence that the travel gaps between females and males are converging as females are becoming more independent both socially and economically. Hence, they can engage in more social activities and hence, travel more (Tilley and Houston 2016). In other words, as females embrace more egalitarian gender roles, they are more likely to travel. On the other hand, males who embrace egalitarian gender role are more accepting toward caring duties in the families and are more responsible to domestic works and hence, are more willing to stay at home in contrast to males with traditional gender roles (Lee and Lee 2018). However, thanks to the technological advancement that allows females and males to work from home and socialize without having to go out of home (Thayer and Ray 2006; Ang 2017). Especially during this 
pandemic where staying at home is encouraged for both males and females.

On the contrary, females who adopt traditional gender role generally staying at home and taking care of the family. Consequently, they may have been more isolated and overload with the increasing household duties during the pandemic with the stay-at-home children or limited social relationships (Power 2020; Robb et al. 2020). Thus, they have increasing need to travel to their hometown, for example to get social support from the family (Yau et al. 2020). Thus, we propose that females and males with egalitarian gender role are more likely to comply with travel restriction than females and males with traditional gender roles. The formal hypothesis is:

$\mathbf{H}_{5}$ Males and females are more likely to comply with travel restrictions when they subscribe to egalitarian gender-role.

\section{The Moderating Role of Situational Pathogen Avoidance}

Literature had well documented individual differences in pathogen avoidance (Duncan et al. 2009; Tybur et al. 2009). Individual differences in pathogen avoidance are a psychological adaptation that aims to help people steer explicit pathogen threats by utilizing a range of social processes (Park and Isherwood 2011; van Leeuwen and Petersen 2018). The social processes may represent both reactive strategies that regulate behaviour when a person perceives an acute pathogen threat and proactive strategies that regulate behaviour in the absence of such situational cues (Schaller 2014). In other words, a reactive strategy is related to acute motive that is activated when individuals encounter momentary pathogen threats (Neuberg et al. 2011). For example, when people encounter an individual who has a nasty cough, it may activate acute pathogen avoidance motive and direct people to lean away, cover faces, or switch seats (Makhanova et al. 2020). In contrast, proactive strategies represent a chronic motive that captures an individual's tendency or predisposition to avoid pathogens over time (Duncan et al. 2009; Tybur et al. 2009).

The COVID-19 pandemic had created an environment where people are advised to avoid people with respiratory problems and to maintain hygiene practices (World Health Organization 2020). Hence, we speculate that the situational aspects impose a greater influence on individuals' tendency to avoid pathogen threats regardless of their chronic motives. Situational pathogen avoidance (SPA) refers to "affective, cognitive, and behavioural responses to hypothetical situations where pathogen transmission is likely" (Makhanova et al. 2020). Furthermore, Makhanova et al. (2020) suggest that SPA reflects an individual's pathogen avoidance motive tendency that is activated in situations that afford an immediate threat of infections.

Previous studies demonstrated that people with high SPA are more likely to respond negatively toward situations that are perceived as pathogen threats, such as people with obesity, the elderly, and foreigners (Faulkner et al. 2004; Miller and Maner 2012). Furthermore, high SPA is also associated with the increasing self and in-group protection behaviours (Navarrete and Fessler 2006; Murray et al. 2019; Makhanova et al. 2020). As we hypothesized that each aspect of gender uniquely influences voluntary compliance to COVID-19 measures, we expect that the SPA will positively moderate the effect of gender dimensions on voluntary adherence to COVID-19 measures. Such that, if the SPA is high when people encounter pathogen cues, they will be more likely to wear masks, practice social distancing, wash hands, and avoid travelling corresponding to the gender dimensions. For example, as we propose that feminine females are more likely to wash hands, this effect will be stronger when the SPA is high. The formal hypothesis is:

$\mathbf{H}_{6}$ SPA positively moderates the relationship between gender (sex, gender psychology, and gender-role) and compliance with COVID-19 measures (social distancing, wearing a mask, washing hands, and travel restrictions).

\section{Research Method}

\section{Sample and Data Collection}

To test our hypotheses, we surveyed respondents in Indonesia. We selected Indonesia as the research context as it is among the countries with high number of confirmed COVID-19 cases and high number of fatalities with more than 5,800 people, making it as the country with highest COVID-19 fatalities among other Southeast Asian countries (Lindsey and Mann 2020). Moreover, as the government decided to open the economy and relaxed the COVID-19 restrictions, promoting voluntary compliance with COVID-19 measures is even more important in Indonesia (Lindsey and Mann 2020). There are no specific requirements to be qualified as respondents in this study. We distribute the link to our survey page on various groups, thus the respondents are snowballed from those groups. We recruited 278 Indonesian respondents with five incomplete responses resulting in 272 usable responses. 


\section{Measurement Instruments}

To measure the main constructs in this research, we adapted scales from previous studies. The scales were back-translated by experts who are fluent both in English and Indonesian as well as understand the research topic to ensure correct wording and conceptual equivalence (Brislin 1970). The scale that was used to measure four voluntary compliance behaviours with COVID-19 measures was adapted from Perugini and Bagozzi (2001) and Parkinson et al. (2017). Each voluntary compliance was measured by one item regarding frequency of conducting the compliance in five-point Likert scale ranging from never (1) to frequently (5). An example for wearing mask voluntary compliance was measured by asking: "How often did you wear masks when you interact with others during the past four weeks?". Other voluntary compliance was asked in a similar manner. However, the item for travel restriction compliance was reversed coded such as: "How often did you travel in the past four weeks", with 1 indicates a high compliance.

To measure masculinity and femininity characteristics, we adopt a binary scale from Spence et al. (1973) as cited in McCabe et al. (2006), with one end indicates traditional gender-role and another end indicates egalitarian genderrole. We use sixteen items to measure this variable yet only nine items were valid for further analysis. The example of items are such as: "not at all aggressive vs very aggressive" and "not at all independent vs very independent". Furthermore, the higher the scores, the more feminine an individual is.

For assessing gender-role, we use two separate scales for males and females adopted from Sherman and Spence (1997). We use sixteen items for both males and females, resulting in each eleven items valid for further analysis as presented in the "Appendix". The sample items for males are as such: "I'd rather have a man as a boss at work" and "When a woman is very smart, I like her better if she does not let it show too much around men". Whereas the corresponding items for females are as such: "When there's an important job to be done, I'd prefer to have a man take the leadership than a woman" and "I prefer to defer to a man rather than trying to be his equal all the time" ( $1=$ strongly disagree; 5 = strongly agree).

Lastly, a five-point Likert scale for SPA was adopted from Makhanova et al. (2020). We use seventeen items to elaborate SPA, and all items were valid for further analysis. The sample items are such as: " Right now, if I were standing next to a person who sneezed I would feel disgusted" and "Right now, I would try to sit on the opposite side of the room if I walked into the room where a person was blowing their nose" $\quad(1=$ strongly disagree;
$5=$ strongly agree). The scale items are listed in the "Appendix".

\section{Results}

\section{Sample Profile}

In total, 272 respondents $\left(58.8 \%\right.$ women, $\left.\mathrm{M}_{\text {age }}=35.5\right)$ were participated in an online survey that was distributed to respondents in Indonesia. Most of the respondents are married $(72.4 \%)$ with various occupation, mainly lecturer, private, and state employee $(23.5 \%, 20.2 \%$, and $20.2 \%$ respectively). Almost half of our respondents have monthly income above IDR5 Million, thus categorized as the middle segment that represents the majority of Indonesian populations (Badan Pusat Statistik 2020). The detailed respondents' profile is presented in Tables 1, 2 .

\section{Assessment of Measurement}

Prior to test the hypotheses, we assessed the reliability and validity of the scales. For the reliability test, the Cronbach's alpha and Composite Reliability (CR) scores were above 0.8 indicates a good reliability for all the scales (Nunnally and Bernstein 1994). To examine the convergent validity, we assess the loading factor of each item with its corresponding scale by conducting Confirmatory Factor Analysis (CFA). As a results, some items have a loading factor below 0.4 and subsequently were excluded from the main analysis (Hair et al. 2010). Sample of items that were deleted are: "Not at all independent", "Women who are very assertive and independent don't have the concern about other people that most women have", and "I'd rather have a man as a boss at work than a woman." The exclusion procedure is consistent with a previous study by Wang et al. (2020) that conducted the study within Chinese context. As the initial scales were developed within a Western context (Spence 1985; McCabe et al. 2006), some of the items may not be relevant within Eastern context and hence, some adjustments were needed. The results of the validity and reliability tests were presented in "Appendix".

To minimize social desirability bias, our questionnaire explained the purpose of the study in detail and emphasis the anonymity of respondents' opinions as well as no right or wrong prejudice regarding their opinions (Mackenzie and Podsakoff 2012). Further, our data collection technique utilizing internet-based research is useful to handle social desirability issue since respondents are free to answer the questionnaire in private and in their most convenient time. Further, we conducted Harmann's single-factor test to ensure that common method variance is not elevating the value of beta estimate. Variance of $15.96 \%$ is produced, 
Table 1 Characteristics of respondents

\begin{tabular}{|c|c|c|}
\hline Variables & $n$ & $\%$ \\
\hline \multicolumn{3}{|l|}{ Age } \\
\hline Below 21 year & 4 & 1.5 \\
\hline $21-30$ years & 69 & 25.4 \\
\hline $31-40$ years & 140 & 51.47 \\
\hline $41-50$ years & 34 & 12.5 \\
\hline 51 years and above & 25 & 9.2 \\
\hline \multicolumn{3}{|l|}{ Gender } \\
\hline Male & 112 & 41,2 \\
\hline Female & 160 & 58,8 \\
\hline \multicolumn{3}{|l|}{ Status } \\
\hline Married & 92 & 33,8 \\
\hline Married with children & 105 & 38,6 \\
\hline Not married & 67 & 24,6 \\
\hline Not married with children & 3 & 1,1 \\
\hline Others & 5 & 1,8 \\
\hline \multicolumn{3}{|l|}{ Occupation } \\
\hline Lecturer & 64 & 23,5 \\
\hline Private employee & 55 & 20,2 \\
\hline State employee & 55 & 20,2 \\
\hline Student & 36 & 13,2 \\
\hline Entrepreneur & 23 & 8,5 \\
\hline Unemployed & 23 & 8,5 \\
\hline Medics & 9 & 3,3 \\
\hline Teacher & 7 & 2,6 \\
\hline \multicolumn{3}{|l|}{ Income } \\
\hline IDR0 & 25 & 9,2 \\
\hline Below IDR2 Million & 46 & 16,9 \\
\hline IDR2-5 Million & 81 & 29,8 \\
\hline Above IDR5 Million & 120 & 44,1 \\
\hline \multicolumn{3}{|l|}{ Family or friends as medics } \\
\hline Yes & 184 & 67,6 \\
\hline No & 88 & 32,4 \\
\hline \multicolumn{3}{|c|}{ Family or friends infected with COVID-19 } \\
\hline No & 207 & 76,1 \\
\hline Yes & 65 & 23,9 \\
\hline
\end{tabular}

indicating that responses' variance do not have certain pattern and thus did not suffer from common method bias (Podsakoff et al. 2003; Malhotra et al. 2006).

\section{Hypothesis Testing}

To test our hypotheses, we conducted an independent sample t-test to understand the effect of biological sex to four COVID-19 measures using IBM SPSS Statistics 26. The result showed a significant indication that female tend to comply with all four COVID-19 measures relative to male as shown in Table 3. Specifically, we found that individual compliances to social distancing measure is significantly different between sex (male vs. female) $(t(270)=-2.688, P<0.05)$. In particular, male statistically showing less inclination to comply with social distancing measure. With regard to wearing mask, male and female are also significantly different in their compliance $(t(270)=-3.125, P<0.05)$ with male are less likely to comply with wearing mask measures. Likewise with washing hands $(\mathrm{t}(270)=-2.900, P<0.05)$, as well as travel restriction measures $(t(270)=-2.369, P<0.05)$. In other words, the results of our study are in line with previous studies that examined the effect of sex types on COVID-19 measures compliance (Okten et al. 2020; Capraro and Barcelo 2020; Galasso et al. 2020; Haischer et al. 2020).

Further, we utilize multigroup analysis using Smart PLS 3 to investigate the effect of other gender dimensions as such personal attributes (femininity-masculinity) and gender-role to represent the multidimensionality of gender and its relations towards four COVID-19 measures. We also test the moderating effect of Situational Pathogen Avoidance on the relationship between gender and COVID-19 measures. The results indicate different phenomenon for different COVID-19 measures (see Table 4).

In terms of social distancing, male or female are not seemed to influence the strategy compliance, proved by no significant relationship. In addition, social distancing is more associated with SPA rather than gender-related factors for general population as well as for males $(\beta=0.205$, $P<001)$. In terms of wearing a mask, general population who regards themselves as more egalitarian $(\beta=0.128$, $P<0.05)$ and high in SPA are more likely to wearing a mask $(\beta=182, P<0.001)$. Furthermore, the male that regard himself as masculine are less likely to wearing a mask $(\beta=-0.026, P<0.05)$.

In terms of washing hands, general population (i.e. both males and females) with high SPA are more likely to wash hands $(\beta=0.218, P<0.05)$. and likewise for females only ( $\beta=0.319, P<0.001)$. For males that are more egalitarian, there are positive and significant moderation effect of SPA ( $\beta=0.214, P<0.05)$ to washing hands. In terms of travel restriction, gender-role significantly affect the strategy $(\beta=-0.136, \quad P<0.05)$. The negative direction indicates that the more egalitarian an individual is, the more likely he/she comply with the travelling restriction regardless the gender.

Table 5 summarizes the results of our hypotheses testing. $\mathrm{H}_{1}$ and $\mathrm{H}_{3}$ are not supported because no significant main effect is found on the relationship between gender and washing hands, as well as no moderating effects of SPA. $\mathrm{H}_{2}$ and $\mathrm{H} 5$ are supported by this study, showing that there are different effects of multidimensionality of gender 
Table 2 Correlation

\begin{tabular}{|c|c|c|c|c|c|c|c|c|}
\hline & SD & WM & WH & NT & PA & GRF & GRM & SPA \\
\hline \multicolumn{9}{|l|}{ SD } \\
\hline WM & $0.495 * *$ & & & & & & & \\
\hline WH & $0.479 * *$ & $0.392 * *$ & & & & & & \\
\hline NT & $0.244 * *$ & $0.145^{*}$ & 0.014 & & & & & \\
\hline PA & $0.197 * *$ & $0.151 *$ & $0.217 * *$ & -0.017 & & & & \\
\hline GRF & $0.166 * *$ & $0.205 * *$ & $0.169 * *$ & 0.078 & -0.032 & & & \\
\hline GRM & $-0.150 *$ & $-0.173 * *$ & $-0.168 * *$ & $-0.153 *$ & 0.033 & $-0.913 * *$ & & \\
\hline SPA & $0.214 * *$ & $0.173 * *$ & $0.223 * *$ & -0.021 & $0.119 *$ & $0.258 * *$ & $-0.197 * *$ & \\
\hline
\end{tabular}

SD social distancing, $W M$ wearing mask, $W H$ washing hands, $N T$ no traveling, $P A$ personal attribute, $G R F$ gender-role female, $G R M$ gender-role male, $S P A$ situational pathology avoidance

$* P<0.05 ; * * P<0.01$;

Table 3 Biological sex and intention to comply with COVID-19 measures

\begin{tabular}{|c|c|c|c|c|}
\hline Variables & Mean & Sig & SD & $t(d f)$ \\
\hline \multicolumn{5}{|c|}{ Social distancing } \\
\hline Male & 4.12 & 0.008 & 0.797 & $-2.688(270)$ \\
\hline Female & 4.43 & & 0.705 & \\
\hline \multicolumn{5}{|c|}{ Wearing mask } \\
\hline Male & 4.46 & 0.002 & 0.628 & $-3.125(270)$ \\
\hline Female & 4.69 & & 0.685 & \\
\hline \multicolumn{5}{|c|}{ Washing hands } \\
\hline Male & 4.19 & 0.004 & 0.665 & $-2.900(270)$ \\
\hline Female & 4.41 & & 0.576 & \\
\hline \multicolumn{5}{|c|}{ Travel restriction } \\
\hline Male & 4.08 & 0.019 & 1.015 & $-2.369(270)$ \\
\hline Female & 4.37 & & 0.949 & \\
\hline
\end{tabular}

that affects intention to comply with COVID-19 measures. Lastly, $\mathrm{H}_{4}$ and $\mathrm{H}_{6}$ are supported partially.

\section{General Discussion}

Our study provides deeper insights into the specific aspects of gender that influence a particular compliance behaviour to COVID-19 measures. Similar to previous studies that conclude females perform better than males in compliance with COVID-19 measures, our study also found that females are more likely to comply with COVID-19 measures across four specific behaviours (i.e. social distancing, wash hands, travelling, and wearing masks) when we measure gender as a biological sex difference. However, a closer look at the gender aspects reveal that the difference in COVID-19 measures compliance is not simply attributable to femininity associated with females and masculinity associated with males.

Such that, when we account for gender psychology and gender-role, we found that males who perceive egalitarian gender-role are more likely to washing hands when they have high SPA. It is partially consistent with our proposition, that males with egalitarian gender-role are more likely to engage in hygiene practices (Brough et al. 2016). We found that males with masculine characteristics are less likely to wear masks in public. We suggest it is because males with masculinity perceive less obligation to protect others and the communities (Annandale and Hunt 1990).

In terms of gender-role, our study shows that the more egalitarian gender-role, the more likely people to comply with travel restrictions for both female and male group. For males, as they subscribe to a more egalitarian gender role, they are expected to stay at home when they subscribe to 
Table 4 Multigroup and moderation results

\begin{tabular}{|c|c|c|c|c|}
\hline & $\begin{array}{l}\text { Social Distancing } \\
\left(R^{2}=0.219\right)\end{array}$ & $\begin{array}{l}\text { Wearing mask } \\
\left(R^{2}=0.226\right)\end{array}$ & $\begin{array}{l}\text { Washing hands } \\
\left(R^{2}=0.281\right)\end{array}$ & $\begin{array}{l}\text { Travel restriction } \\
\left(R^{2}=0.212\right)\end{array}$ \\
\hline \multicolumn{5}{|c|}{ Total sample $(n=272)$} \\
\hline Femininity & 0.091 & 0.013 & 0.101 & -0.033 \\
\hline Masculinity & 0.097 & -0.016 & 0.112 & 0.018 \\
\hline Gender-role & -0.037 & $0.128^{*}$ & -0.079 & $-0.136^{*}$ \\
\hline SPA & $0.205^{* *}$ & $0.182 * *$ & $0.218 * *$ & -0.011 \\
\hline Femininity*SPA & -0.126 & 0.094 & 0.010 & 0.011 \\
\hline Masculinity*SPA & 0.081 & -0.109 & -0.014 & -0.034 \\
\hline Gender-role*SPA & 0.047 & 0.083 & 0.056 & -0.009 \\
\hline \multicolumn{5}{|l|}{ Male $(n=112)$} \\
\hline Femininity & 0.269 & 0.031 & 0.276 & 0.151 \\
\hline Masculinity & 0.002 & $-0.026^{*}$ & 0.014 & -0.083 \\
\hline Gender-role & -0.092 & 0.208 & -0.051 & -0.072 \\
\hline SPA & $0.196^{*}$ & 0.183 & 0.092 & 0.006 \\
\hline Femininity*SPA & -0.065 & 0.116 & 0.189 & 0.216 \\
\hline Masculinity*SPA & 0.083 & -0.083 & -0.122 & -0.182 \\
\hline Gender-role*SPA & 0.150 & 0.114 & $0.214^{*}$ & 0.027 \\
\hline \multicolumn{5}{|l|}{ Female $(n=160)$} \\
\hline Femininity & -0.005 & 0.019 & 0.042 & -0.129 \\
\hline Masculinity & 0.176 & 0.098 & 0.172 & 0.083 \\
\hline Gender-role & 0.081 & 0.112 & 0.018 & -0.078 \\
\hline SPA & 0.159 & 0.078 & $0.319 * *$ & -0.054 \\
\hline Femininity*SPA & -0.135 & 0.089 & -0.160 & -0.054 \\
\hline Masculinity*SPA & 0.045 & -0.114 & 0.046 & -0.011 \\
\hline Gender-role*SPA & -0.055 & -0.010 & -0.004 & -0.035 \\
\hline
\end{tabular}

$* P<0.05, * * P<0.01$

the egalitarian gender-role (Tilley and Houston 2016). Whereas for females, although they are expected to be on employment when they subscribe to egalitarian gender roles, the advance of technology allows them to work from home. In addition, company policy and government regulation also increasingly support working from home, especially during this pandemic. Thus, as females who adopt egalitarian gender roles are still able to actualize themselves even they are staying at home, they are more likely to comply with travel restriction than females who adopt traditional gender roles.

Table 5 Summary of results

\begin{tabular}{|c|c|c|}
\hline \multicolumn{2}{|c|}{ Hypotheses } & \multirow{2}{*}{$\begin{array}{l}\text { Results } \\
\text { Not supported }\end{array}$} \\
\hline $\mathrm{H}_{1}$ & Females and males are more (less) likely to wash hands when they have feminine (masculine) characteristics & \\
\hline $\mathrm{H}_{2}$ & $\begin{array}{l}\text { Males are more likely to wash hands when they subscribe to the egalitarian gender-role, while the effect is insignificant for } \\
\text { females }\end{array}$ & $\begin{array}{l}\text { Partially } \\
\text { supported }\end{array}$ \\
\hline $\mathrm{H}_{3}$ & $\begin{array}{l}\text { Females and males are more (less) likely to comply with social distancing measures when they have masculine (feminine) } \\
\text { characteristics }\end{array}$ & Not supported \\
\hline $\mathrm{H}_{4}$ & Females and males are more (less) likely to wear a mask when they have masculine (feminine) characteristics & Not supported \\
\hline $\mathrm{H}_{5}$ & Males and females are more likely to comply with travel restrictions when they subscribe to the egalitarian gender-role & Supported \\
\hline $\mathrm{H}_{6}$ & $\begin{array}{l}\text { SPA positively moderates the relationship between gender (sex, gender psychology, and gender-role) and compliance with } \\
\text { COVID-19 measures (social distancing, wearing a mask, washing hands, and travel restrictions) }\end{array}$ & $\begin{array}{l}\text { Partially } \\
\text { supported }\end{array}$ \\
\hline
\end{tabular}


As a supplementary analysis, the results show that SPA has a direct effect on social distancing, wearing masks, and wash hands, however, the moderating effect is not significant across all behaviours. Thus we can conclude that when people are exposed to pathogen cues, the pathogen avoidance motive is activated. Hence, they are more likely to comply with social distancing, wearing masks, and washing hands. However, it does not affect the compliance on travel restrictions. It is presumably because social distancing practices and wearing masks were advised for people who have to travel (Dzisi and Dei 2020), people tend to perceive that travelling is safe as long as they comply with social distancing measures and wearing masks.

\section{Theoretical Contributions}

This research offers three main theoretical contributions. First, our study reveals the underlying gender aspects that influence the different responses toward COVID-19 measures between females and males. Such that, the masculinity and femininity qualities as well as the gender-role for females and males that are related to the distinct responses to COVID-19 measures. Furthermore, although the results of previous studies generally suggest that females with their femininity are better in compliance with COVID-19 measures (Okte et al. 2020; Capraro and Barcelo 2020; Galasso et al. 2020; Haischer et al. 2020), accounting for other gender dimensions we found that females are not necessarily better than males. More importantly, it is the gender-role dimension of the individuals that are more influential for COVID-19 prevention behaviours.

Second, the literature suggests that individuals' strategies to address health issues may vary depending on their motivations (Wilson et al. 2004; Rosenfeld 2019). For instance, people with health-motivation and ethics-motivation may perform diverse strategies when they choose vegetarian options (Rosenfeld 2019). As gender dimensions may also represent different motivations for females and males (Meece et al. 2006; Mehta and Strough 2010), we found that the manifested behaviours to address COVID-19 are also different. As COVID-19 measures comprise various types of actions, it is crucial to examine each behaviour separately. Consistently, our study reveals that each behaviour is related to a different aspect of gender.

Third, although our research demonstrated the direct effect of SPA on compliance to COVID-19 measures, we did not find a significant moderating effect of SPA to wearing masks, washing hands, and compliance with travel restrictions. In addition, we found that SPA positively moderates the effect of gender role on washing hands for males. This is consistent with our hypothesis that males with egalitarian gender roles are more likely to perform hygiene practice and the effect is increased with high SPA (Navarrete and Fessler 2006; Murray et al. 2019; Makhanova et al. 2020).

\section{Practical Implications}

This research also provides several main contributions from the practical perspective, particularly to design an innovative COVID-19 management strategy through social marketing and public policy. First, generally, based on previous studies, social marketers might be advised to use femininity clues to promote COVID-19 measures compliance (Okten et al. 2020; Capraro and Barcelo 2020; Galasso et al. 2020; Haischer et al. 2020). However, although we found that females demonstrate higher compliance to COVID-19 measures, it is not due to femininity nature of females. We found that egalitarian gender role plays a more significant part to explain compliance with COVID-19 measures. Thus, applying femininity approach in social marketing will be misleading. A clear example in Indonesia is when a female medical doctor named dr. Reisa Broto Asmoro who has a strong feminine characteristic was appointed as presidential spokesperson for COVID-19 yet received many criticism and invited a lot of skepticism from general public (Tribun News 2020; Warta Ekonomi 2020). Thus, we suggest that encouraging egalitarian gender role is more effective to promote compliance with COVID-19 measures (instead of promoting femininity as suggested by previous studies).

Literature suggests that masculinity and femininity represent two separate dimensions that exist within an individual and can be activated by specific contextual cues (Wong et al. 2015; Guillet et al. 2019). Consistently, previous studies have shown that marketers consistently use gender cues to induce a positive perception of masculinity or femininity characteristics (see Hess and Melnyk (2016) for a review). Thus, social marketers may portray egalitarian gender role to promote COVID-19 measures compliance by endorsing female celebrity who have the masculine qualities (e.g. successful and competence) promoting the travel restriction policy. For males, marketers may promote positive masculinity that associates masculinity with positive behaviours, such as healthy behaviour and caring for the community by wearing face mask (Berke et al. 2012). Whereas males who stay at home can be portrayed or described as having positive masculinity quality (i.e. masculine individuals who have positive and healthy behaviours), despite traditionally males are expected to work outside (Berke et al. 2012). For females, public policy and employers may promoting egalitarian role by maintaining the flexibility to work from home by 
investing in communication applications that allow people to work remotely as it might be the only way to reduce the travel frequency so that females can keep still actualize themselves as their counterparts do while reducing their traveling frequency.

Second, we found that males with egalitarian principle are more likely to wash their hands when their SPA is high. Simultaneously, social marketers may also apply egalitarian gender-role principle in social campaigns. Such that, by portraying and promoting males who take care of family and children or males who works from home as a COVID19 champions to increase intention to washing their hands. Simultaneously, we can also increase their compliance to wash hands by combining social campaign cues that can increase their SPA (i.e. portraying people who are sick and contagious).

Third, we found that SPA is effective both as a main predictor of COVID-19 measures compliance and to enhance the effect of gender aspects, particularly in compliance with washing hands measure for males. Thus, we suggest that social marketers may include stimuli that can increase SPA as an alternative strategy to promote compliance to COVID-19 measures, ${ }^{1}$ such as by showing a picture of people infected with COVID-19 may increase their intention to comply with COVID-19 measures (Makhanova et al. 2020).

In conclusion, understanding gender influence on compliance with COVID-19 measures help policy makers and social marketers to enact strategic flexibility by precipitating changes and adapting the social marketing strategies to environmental changes (i.e. COVID-19 pandemic) via continuous rethinking of the existing marketing strategies, especially to promote compliance to COVID-19 measures (Roberts and Stockport 2009). Using our findings, policy makers and social marketers may formulate social marketing strategies by considering the relevant aspects from the stakeholders' (i.e. individual community member) perspectives who mainly affected and involved in this pandemic situation (Sushil 2014; Elias 2019). In other words, as the policy makers and social marketers expects people to change their initial behaviours due to the pandemic, policy makers and social marketers need to be adaptive as well in designing the social policy and campaign to promote appropriate change in people's behaviours (i.e. compliance to COVID-19 measures) by utilizing different social marketing communication strategies according to gender characteristics of the individuals

\footnotetext{
${ }^{1}$ We have run a multilinear regression analysis with interaction using SPSS to test an alternative model which is the effect of SPA as a main variable and gender dimensions as moderating variables (SPA*Sex, $\mathrm{SPA}^{*}$ gender role, SPA*gender psychology) and the results were insignificant for all dependent variables except for SPA*sex and washing hands practice $(\beta=0.353, P<0.001)$.
}

(Sushil 2014; Elias 2019; Shalender and Yadav 2019; Shukla et al. 2019).

\section{Limitations and Future Research}

We acknowledge several limitations of our study. First, although WHO had recommended several COVID-19 measures, our research is limited to four particular behaviours that currently deemed as the primary measures to prevent the coronavirus spread (World Health Organization 2020). However, as there has been no agreement to which measure that is most effective to prevent the spread of coronavirus (Begley 2020), future research should examine other types of COVID-19 measures such as avoiding contact with animals, banning gatherings, and so on. As our study reveals that each type of behaviour is influenced by different motivations, examining various types of COVID19 measures is increasingly essential.

Second, our study is limited to the Indonesian context as Indonesia represents one amongst the other countries that have relaxed COVID-19 measures (Sutrisno 2020). However, discussion over gender along with the findings of our study reveals that gender involves social norms as well as cultural influences (Kret 2016; Loegel et al. 2017; Hofstede Insights 2020). For instance, Indonesia has a higher masculinity dimension than most countries in Europe, making masculine-related behaviours are socially expected (Hofstede Insights 2020). Thus, although this research mainly focused on gender psychology (masculinity vs femininity) at the individual level, future research would provide broader insights when they account for cultural context.

Third, despite providing more in-depth insights about the gender-role in voluntary compliance to COVID-19 measures compared to previous studies that treated gender as a dichotomous biological variable, this study opens further opportunities to advance the understanding of gender. Twenge (1999) suggested more aspects of gender that were not covered in this study to be explored, such as occupations, abilities, leisure interests, physical/material attribute, social and personal relationship, self-ascribed or global masculinity and femininity, stylistic and symbolic behaviours that probably are relevant to explain individuals' voluntary compliance to COVID-19 measures.

Funding Not applicable.

Data Availability Primary data is available on request.

Compliance with ethical standards: Not applicable.

Conflict of interest All author declares no conflict of interest. 
Code availability Not applicable.

\section{Appendix}

See Table 6.

Table 6 Validity and reliability

\begin{tabular}{lrrr}
\hline Variables & Load $n$ & $\alpha$ & CR
\end{tabular}

Personal attributes

Not at all understanding of others/Very understanding of others

$\begin{array}{llll}0.824 & 9 & 0,828 & 0,897\end{array}$

Not at all aware of feelings of others/Very aware of feelings of others $\quad 0.785$

Very cold in relations with others/Very warm in relations with others 0.755

$\begin{array}{lr}\text { Very } \text { rough/Very gentle } & 0.667\end{array}$

$\begin{array}{ll}\text { Can make decisions easily/Has difficulty making decisions } & 0.783\end{array}$

$\begin{array}{lr}\text { Very passive/Very active } & 0.714\end{array}$

$\begin{array}{lr}\text { Not at all competitive/Very competitive } & 0.679\end{array}$

$\begin{array}{ll}\text { Feels very inferior/Feels very superior } & 0.542\end{array}$

Not at all able to devote self completely to others/Able to devote self completely to others 0.526

Gender-role Female

When I'm with a man I want to impress, I try to act very feminine

$\begin{array}{llll}0.747 & 11 & 0,834 & 0,871\end{array}$

When I'm with women I want to impress, I try to act very feminine 0.690

When I'm playing a sport with a man, I feel better about him if he wins 0.686

I sometimes try to get my way by acting "feminine." 0.683

I sometimes treat men as if they were stronger and smarter than they really are $\quad 0.652$

When men and women are in the same organization, women should let the men take the lead and not try to take over 0.600

When there's an important job to be done, I'd prefer to have a man take the leadership than a woman 0.589

$\begin{array}{ll}\text { I prefer to defer to a man rather than trying to be his equal all the time } & 0.587\end{array}$

$\begin{array}{ll}\text { I would not like people to think of me as unfeminine } & 0.547\end{array}$

When I'm around men, I'm likely to act more helpless than I really feel 0.521

Masculine men who make me feel they can take care of me turn me on $\quad 0.465$

Gender-role Male

When there's an important job to be done, I'd prefer to have a man as leader than a woman

$\begin{array}{llll}0.730 & 11 & 0,832 & 0,870\end{array}$

When men and women are in the same organization, women should let the men take the lead and not try to take over 0.694

I prefer a woman who defers to me rather than trying to be my equal all the time 0.688

$\begin{array}{ll}\text { I prefer a woman who dresses in feminine styles } & 0.655\end{array}$

I don't have much respect for a man who allows himself to be led around by his wife or girlfriend, even if it's not done 0.602 obviously

$\begin{array}{ll}\text { Losing an argument to a woman is more annoying than losing to a man } & 0.601\end{array}$

$\begin{array}{lr}\text { The kind of woman I like is soft and feminine } & 0.599\end{array}$

$\begin{array}{ll}\text { Feminine women who make me feel that I should take care of them turn me on } & 0.590\end{array}$

$\begin{array}{ll}\text { When I'm with men I want to impress, I try to act very masculine } & 0.574\end{array}$

$\begin{array}{ll}\text { I'd rather have a man as a boss at work than a woman } & 0.511\end{array}$

When a woman is very smart, I like her better if she doesn't let it show too much around men 0.500

Situational Pathogen Avoidance

Right now, I would try to sit on the opposite side of the room if I walked into the room where there was a person blowing their nose

Right now, if I heard that a friend had the flu, I would avoid going to their house or apartment

0.740

$17 \quad 0,903 \quad 0,921$

Right now, if a person looked like they were sick, I would be willing to shake their hand. ${ }^{\mathrm{r}}$

0.731

Right now, I would be disgusted if I was in the bathroom and someone started throwing up in the stall next to me

Right now, I would want to wash my hands immediately, if I shook hands with a person with sweaty palms

0.702

Right now, if someone coughed next to me without covering their mouth, I would move away from them

0.698

0.681 
Table 6 continued

\begin{tabular}{|c|c|c|c|}
\hline Variables & Load $n$ & $\alpha$ & $\mathrm{CR}$ \\
\hline Right now, I would be happy to sit close to someone who just finished an intense workout. ${ }^{r}$ & 0.680 & & \\
\hline Right now, I would feel comfortable finishing a sandwich that a friend of a friend took a bite out of. ${ }^{r}$ & 0.674 & & \\
\hline Right now, I would be bothered by sitting in a seat (that is still warm) that a stranger just got up from & 0.663 & & \\
\hline Right now, I would be grossed out if I shook a stranger's hand & 0.658 & & \\
\hline Right now, it would make me uncomfortable to touch a door handle in a public restroom & 0.637 & & \\
\hline Right now, I would be disgusted if I noticed a person sitting next to me was bleeding from a wound on their arm & 0.630 & & \\
\hline Right now, if a stranger tried to hug me I would not feel comfortable & 0.624 & & \\
\hline Right now, if I was standing next to a person who sneezed I would feel disgusted & 0.536 & & \\
\hline $\begin{array}{l}\text { Right now, if I met a person who told me that they had sex with a stranger the night before, I would not want to } \\
\text { associate with that person }\end{array}$ & 0.532 & & \\
\hline $\begin{array}{l}\text { Right now, I would have no problem taking out a mouldy berry out of the package and eating the berry that was } \\
\text { adjacent to it. }{ }^{r}\end{array}$ & 0.475 & & \\
\hline Right now, if I saw a stray cat or dog that seemed friendly, I would be unlikely to pet it & 0.407 & & \\
\hline
\end{tabular}

$n$ number of items; $\alpha=$ Cronbach's Alpha; $C R$ composite reliability

\section{References}

Annandale, E., \& Hunt, K. (1990). Masculinity, femininity and sex: An exploration of their relative contribution to explaining gender differences in health. Sociology of Health and Illness, 12(1), 24-46.

Badan Pusat Statistik. (2020). Pendapatan Nasional Indonesia 2015-2019. Jakarta: Badan Pusat Statistik.

Bailliet, D., Li, N. P., Macfarlan, S. J., \& Van Vugt, M. (2011). Sex differences in cooperation: A meta-analytic review of social dilemmas. Psychological Bulletin, 137(6), 881.

Berke, D. S., Sloan, C. A., Parrott, D., \& Zeichner, A. (2012). Effects of female gender role and gender norm conformity on aggression in men: Does positive masculinity reduce the risk? Psychology of Men and Masculinity, 13(4), 367.

Begley, S. (2020). www.statnews.com. https://www.statnews.com/ 2020/04/09/social-distancing-controlling-COVID-19-which-mea sures-are-most-effective/. Accessed 1 Aug 2020.

Bitan, D. T., et al. (2020). FearofCOVID-19scale: Psychometriccharacteristics, reliabilityandvalidityintheIsraelipopulation. Psychiatry Research, 289, 97.

Blackstone, A. (2003). Gender roles and society. In J. R. Miller, R. M. Lerner, \& L. B. Schiamberg (Eds.), Human ecology: An encyclopedia of children, families, communities, and environments (pp. 335-338). California: Springer.

Brebner, J. (2003). Gender and emotions. Personality and Individual Differences, 34, 387-394.

Brislin, R. W. (1970). Back-translation for cross-cultural research. Journal of Cross-cultural Psychology, 1(3), 185-216.

Brouard, S., Vasilopoulos, P., \& Becher, M. (2020). Sociodemographic and psychological correlates of compliance with the COVID-19 public health measures in France. Canadian Journal of Political Science, 53, 253-258.

Brough, A. R., et al. (2016). Is eco-friendly unmanly? The green feminine stereotype and its effect on sustainable consumption. Journal of Consumer Research, 43, 567-582.

Brown, M., Keefer, L. A., Sacco, D. F., \& Bermond, A. (2019). Is the cure a wall? Behavioral immune system responses to a disease metaphor for immigration. Evolutionary Psychological Science, 5(3), 343-356.
Capraro, V. \& Barcelo, H. (2020). The effect of messaging and gender on intentions to wear a face covering to slow down COVID-19 transmission, New York: arXiv.

Champoux-Paille, L. \& Croteau, A. -M. (2020). www.theconversa tion.com. https://theconversation.com/why-women-leaders-areexcelling-during-the-coronavirus-pandemic-138098. Accessed 26 August 2020.

Clark, C., Davila, A., Regis, M., \& Kraus, S. (2020). Predictors of COVID-19 voluntary compliance behaviors: An international investigation. Global Transitions, 2, 76-82.

Courtenay, W. H. (2000). Constructions of masculinity and their influence on men's well-being: A theory of gender and health. Social Science and Medicine, 50(10), 1385-1401.

Crane, M., \& Markus, H. (1982). Gender identity: The benefits of self-schema approach. Journal of Personality and Social Psychology, 43(6), 1195-1197.

Davis, T. L. (1995). Gender differences in masking negative emotions: Ability or motivation. Developmental Psychology, 31(4), 660-667.

Deaux, K. (1985). Sex and gender. Annual Review Psychology, 36, 49-81.

Drydakis, N., et al. (2018). Masculine vs feminine personality traits and women's employment outcomes in Britain. International Journal of Manpower, 39(4), 621-630.

Duncan, L. A., Schaller, M., \& Park, J. H. (2009). Perceived vulnerability to disease: Development and validation of a 15-item self-report instrument. Personality and Individual Differences, 47(6), 541-546.

Dzisi, E. K. J., \& Dei, O. A. (2020). Adherence to social distancing and wearing of masks within public transportation during the COVID-19 pandemic. Transportation Research Interdisciplinary Perspectives, 7, 53.

Edwards, V. J., \& Spence, J. T. (1987). Gender-related traits, stereotypes, and schemata. Journal of Personality and Social Psychology, 53(1), 146-154.

Elias, A. A. (2019). Strategy development through stakeholder involvement: A New Zealand study. Global Journal of Flexible Systems Management, 20(4), 313-322.

Elliot, K. (2016). Caring masculinities: Theorizing an emerging concept. Men and Masculinities, 19(3), 240-259. 
Evans, S., \& Bahrami, H. (2020). Super-flexibility in practice: Insights from a crisis. Global Journal of Flexible Systems Management, 21(3), 207-214.

Faulkner, J., Schaller, M., Park, J. H., \& Duncan, L. A. (2004). Evolved disease-avoidance mechanisms and contemporary xenophobic attitudes. Group Processes and Intergroup Relations, 7(4), 333-353.

Fleming, P. J., \& Agnew-Brune, C. (2015). Current trends in the study of gender norms and health beahviours. Current Opinion in Psychology, 5, 72-77.

Fletcher, G. J., \& Kerr, P. S. (2010). Through the eyes of love: Reality and illusion in intimate relationship. Psychological Bulletin, $136(4), 627$.

Galasso, V., et al. (2020). Gender differences in COVID-19 related attitudes and behavior: Evidence from a panel survey in eight OECD countries. Massachusetts: National Bureau of Economic Research.

Galdas, P. M., Johnson, J. L., Percy, M. E., \& Ratner, P. A. (2010). Help seeking for cardiac symptoms: Beyond the masculinefeminine binary. Social Science and Medicine, 71(1), 18-24.

Ganuthula, V. R. R., \& Sinha, S. (2019). Flexibility in cognitive functioning: The play of paradox. Global Journal of Flexible Systems Management, 20(4), 303-312.

Gartzia, L., Ryan, M. K., Balluerka, N., \& Aritzeta, A. (2012). Think crisis-think female: Further evidence. European Journal of Work and Organizational Psychology, 21(4), 603-628.

Guillet, B. D., Pavesi, A., Hsu, C. H. C., \& Weber, K. (2019). Is there such a thing as feminine leadership? Being a leader and not a man in the hospitality industry. International Journal of Contemporary Hospitality Management, 31(7), 2970-2993.

Hadden, J. (2020). www.businessinsider.com. https://www.businessin sider.com/how-people-use-makeup-with-face-masks-during-thecoronavirus-2020-4? $\mathrm{r}=\mathrm{AU} \& \mathrm{IR}=\mathrm{T}$. Accessed 29 August 2020.

Hair, J. F., Black, W. C., Babin, B. J., \& Anderson, R. E. (2010). Multivariate Data Analysis (7th ed.). New Jersey: Prentice Hall.

Haischer, M. H., et al. (2020). Who is wearing mask? Gender-, age-, and location-related differences during the COVID-19 pandemic. Connecticut: MedRxiv.

Hart, C. G., Saperstein, A., Magliozzi, D., \& Westbrook, L. (2019). Gender and health: Beyond binary categorical measurement. Journal of Health and Social Behaviour, 60(1), 101-118.

Hess, A. C., \& Melnyk, V. (2016). Pink or blue? The impact of gender cues on brand perceptions. European Journal of Marketing, 50(9/10), 1550-1574.

Hofstede Insights (2020). www.hofstede-insights.com. https://www. hofstede-insights.com/country-comparison/indonesia/. Accessed 31 August 2020.

Hyde, J. S. (2016). Sex and cognition: Gender and cognitive functions. Current Opinion in Neurobiology, 38, 53-56.

Kachel, S., Steffens, M. C., \& Niedlich, C. (2016). Traditional masculinity and femininity: Validation of a new scale assessing gender roles. Frontiers in Psychology, 3, 79.

Kim, J., Han, W., Kim, D. T., \& Paramita, W. (2013). Is beauty in the eye of the beholder? Gender and beauty in the cosmetics sector: A comparative study of Indonesia and Korea. Marketing Intelligence and Planning, 31(2), 127-140.

Klatt, J., Eimler, S. C., \& Kramer, N. C. (2016). Makeup your mind: The impact of styling on perceived competence and warmth of female leaders. The Journal of Social Science, 156(5), 483-497.

Kret, M. E. (2016). Faces with light makeup are better recognized than faces with heavy makeup. Frontiers in Psychology. https://doi.org/10.3389/fpsyg.2016.00226.

Lee, J. Y., \& Lee, S. J. (2018). Caring is masculine: Stay at home fathers and masculine identity. Psychology of Men and Masculinity, 19(1), 47.
Lee, Y., Hickman, M., \& Washington, S. (2007). Household type and structure, time-use pattern, and trip chaining behavior. Transportation Research Part A Policy and Practice, 41(10), 1004-1020.

Leszczynski, J. P., \& Strough, J. (2008). The contextual specificity of masculinity and femininity in early adolescence. Social Development, 17(3), 719-736.

Levy, G. D., \& Carter, B. D. (1989). Gender schema, gender constancy, and gender-role knowledge: The role of cognitive factors in preschoolers' gender-role stereotype attributions. Developmental Pscyhology, 25(3), 444-449.

Lindsey, T. \& Mann, T. (2020). www.theconversation.com. https://theconversation.com/indonesias-coronavirus-fatalitiesare-the-highest-in-southeast-asia-so-why-is-jokowi-rushing-toget-back-to-business-144059. Accessed 01 September 2020.

Loegel, A., Courreges, S., Morizot, F., \& Fontayne, P. (2017). Make up, an essential tool to manage social expectations surrounding femininity? Movement and Sport Sciences, 96, 19-25.

Lott, B., \& Maluso, D. (2002). Gender development: Social learning. In J. Worrel (Ed.), Encyclopedia of women and gender: Sex similarities and differences and the impact of society on gender (p. 537). San Diego: Academic Press.

Lund, E. M., \& Miller, S. L. (2014). Is obesity un-American? Disease concerns bias implicit perceptions of national identity. Evolution and Human Behavior, 35(4), 336-340.

Lyons, G., Chatterjee, K., Beecroft, M., \& Marsden, G. (2002). Determinants of travel demand-exploring the future of society and lifestyles in the UK. Transport Policy, 9(1), 17-27.

MacKenzie, S. B., \& Podsakoff, P. M. (2012). Common method bias in marketing: Causes, mechanisms, and procedural remedies. Journal of Retailing, 88(4), 542-555.

Maclean, K. (2020). www.theconversation.com. https://theconver sation.com/women-leaders-and-coronavirus-look-beyond-stereo types-to-find-the-secret-to-their-success-141414. Accessed 26 August 2020.

Maes, M., Klimstra, T., Van den Noortgate, W., \& Goossens, L. (2015). Factor structure and measurement invariance of a multidimensional loneliness scale: Comparison across gender and age. Journal of Child and Family Studies, 24(6), 1829-1837.

Maes, M., et al. (2019). Gender differences in loneliness across the lifespan: A meta-analysis. European Journal of Personality, 33, 642-654.

Makhanova, A., Miller, S. L., \& Maner, J. K. (2015). Germs and the out-group: Chronic and situational disease concerns affect intergroup categorization. Evolutionary Behavioural Sciences, $9(1), 8$.

Makhanova, A., Plant, A. E., \& Maner, J. K. (2020). Capturing fluctuations in pathogen avoidance: The situational pathogen avoidance scale. Evolutionary Psychological Science, 5, 71.

Malhotra, N. K., Kim, S. S., \& Patil, A. (2006). Common method variance in IS research: A comparison of alternative approaches and a reanalysis of past research. Management science, 52(12), $1865-1883$.

McCabe, C. A., Ingram, R., \& Dato-on, M. C. (2006). The business of ethics and gender. Journal of Business Ethics, 64, 101-116.

McConnell, A. R. (2011). The multiple self-aspects framework: Selfconcept representation and its implications. Personality and Social Psychology Review, 15(1), 3-27.

McQuaid, R. W., \& Chen, T. (2012). Commutting times-the role of gender, children, and part-time work. Research in Transportation Economics, 34(1), 66-73.

Meece, J. L., Glienke, B. B., \& Burg, S. (2006). Gender and motivation. Journal of Social Psychology, 44, 351-373.

Mehta, C. M., \& Dementieva, Y. (2017). The contextual specificity of gender: Femininity and masculinity in college students' same and other-gender peer context. Sex Roles, 76, 604. 
Mehta, C. M., \& Strough, J. (2010). Gender segregation and gendertyping in adolescence. Sex Roles, 63, 251-263.

Meier-Pesti, K., \& Penz, E. (2008). Sex or gender? Expanding the sex-based view by introducing masculinity and femininity as predictors of financial risk taking. Journal of Economic Psychology, 29, 180-196.

Miller, S. L., \& Maner, J. K. (2012). Overprerceiving disease cues: The basic cognition of the behavioral immune system. Journal of Personality and Social Pscyhology, 102(6), 1198.

Miyose, C., \& Engstrom, E. (2015). Boys over flowers: Korean soap opera and the blossoming of a new masculinity. Popular Culture Review, 26(2), 4-15.

Murray, D. R., Kerry, N., \& Gervais, W. M. (2019). On disease and deontology: Multiple tests of the influence of disease threat on moral vigilance. Social Psychology and Personality Science, $10(1), 44-52$.

Navarrete, C. D., \& Fessler, D. M. T. (2006). Disease avoidance and ethnocentrism: The effects of disease vulnerability and disgust sensitivity on intergroup attitudes. Evolution and Human Behavior, 27(4), 270-282.

Neale, L., Robbie, R., \& Martin, B. (2016). Gender identity and brand incongruence: When in doubt, pursue masculinity. Journal of Strategic Marketing, 24(5), 347-359.

Neuberg, S. L., Kenrick, S. D., \& Schaller, M. (2011). Human threat management systems: Self-protection and disease avoidance. Neuroscience and Biobehavioral Reviews, 35(4), 1042-1051.

Niedlich, C., et al. (2015). Ironic effects of sexual minority group membership: Are lesibans less susceptible to invoking negative female stereotypes than heterosexual women? Archives of Sexual Behavior, 44(5), 1439-1447.

Nunnally, J. C., \& Bernstein, I. H. (1994). The assessment of reliability. Psychometric theory (pp. 248-292). New York: McGraw-Hill.

Okten, I. O., Gollwitzer, A. \& Oettingen, G. (2020) www.behavioral policy.org. https://behavioralpolicy.org/articles/gender-differenc es-in-preventing-the-spread-of-coronavirus/. Accessed 0101 2021.

Parkinson, J., David, P., \& Rundle-Thiele, S. (2017). Self-efficacy or perceived behavioural control: Which influences consumers' physical activity and healthful eating behavior maintenance? Journal of Consumer Behaviour, 16(5), 413-423.

Park, J. H., \& Isherwood, E. (2011). Effects of concerns about pathogens on ceonservatism and anti-fat prejudice: Are they mediated by moral institutions? The Journal of Social Psychology, 151(4), 391-394.

Paul, S. K., \& Chowdhury, P. (2020). Strategies for managing the impacts of disruptions during COVID-19: an example of toilet paper. Global Journal of Flexible Systems Management, 21(3), 283-293.

Perugini, M., \& Bagozzi, R. P. (2001). The role of desires and anticipated emotions in goal-directed behaviours: Broadening and deepening the theory of planned behavior. British Journal of Social Psychology, 40(1), 79-98.

Pinna, M. (2020). Do gender identities of femininity and masculinity affect the intention to buy ethical products? Psychology and Marketing, 37(3), 384-397.

Podsakoff, P. M., MacKenzie, S. B., Lee, J.-Y., \& Podsakoff, N. P. (2003). Common method biases in behavioral research: A critical review of the literature and recommended remedies. Journal of Applied Psychology, 88(5), 879-903.

Power, K. (2020). The COVID-19 pandemic has increased the care burden of women and families. Sustainability Science, Practice and Policy, 16(1), 67-73.

Rader, B., White, L. F., Burns, M. R., Chen, J., Brilliant, J., Cohen, J., et al. (2020). Mask wearing and control of SARS-CoV-2 transmission in the United States. medRxiv. https://doi.org/ 10.1101/2020.08.23.20078964.

Robb, C. E., et al. (2020). Associations of social isolation with anxiety and depression during the early COVID-19 pandemic: A survey of older adults in London UK. Frontiers in PSychiatry, 5 , 25. https://doi.org/10.3389/fpsyt.2020.591120.

Roberts, N., \& Stockport, G. J. (2009). Defining strategic flexibility. Global Journal of Flexible Systems Management, 10(1), 27-32.

Rosenfeld, D. L. (2019). Why some choose the vegetarian option: Are all ethical motivations the same? Motivation and Emotion, 43, $400-411$

Rougharden, J. (2003). Evolution's rainbow: diversity, gender, and sexuality in nature and people (1st ed.). California: University of California Press.

Ruffner, Z. (2020). www.vogue.com. https://www.vogue.com/article/ face-mask-skin-care-makeup-tips. Accessed 29 August 2020.

Schaller, M. (2014). When and how disgust is and is not implicated in the behavioral immune system. Evolutionary Behavioural Science, 8(4), 251.

Shalender, K., \& Yadav, R. K. (2019). Strategic flexibility, manager personality, and firm performance: The case of Indian Automobile Industry. Global Journal of Flexible Systems Management, 20(1), 77-90.

Sherman, P. J., \& Spence, J. T. (1997). A comparison of two cohorts of college students in responses to the Male-Female Relations Questionnaire. Psychology of Women Quarterly, 21(2), 265-278.

Shukla, S. K., Sushil, \& Sharma, M. K., (2019). Managerial paradox toward flexibility: Emergent views using thematic analysis of literature. Global Journal of Flexible Systems Management, 20(4), 349-370.

Skitka, L. J., \& Maslach, C. (1990). Gender roles and the categorization of gender-relevant behaviour. Sex Roles, 22(3/4), 133.

Spence, J. T. (1985). Gender identity and its implications for the concepts of masculinity and femininity. In T. P. Sonderegger (Ed.), Psychology and Gender (p. 59). Lincoln: University of Nebraska Press.

Spence, J. T., Helmreich, R., \& Stapp, J. (1973). A short version of the attitudes toward Women Scale. Bulletin of Psychonomic Society, 2(4), 219-220.

Springer, K. W., \& Mouzon, D. M. (2019). One step toward more research on aging masculinities: Operationalizing the hegemonic masculinity for older men scale. The Journal of Men's Studies, 27(2), 183-203.

Strough, J., et al. (2007). From adolescent to later adulthood: Femininity, masculinity, and androgyny in six age groups. Sex Roles, 57, 385-396.

Su, R., Rounds, J., \& Armstrong, P. I. (2009). Men and things, women and people: A meta-analysis of sex differences in interests. Psychological bulletin, 135(6), 859.

Sushil, X. (1997). Flexible systems management: An evolving paradigm. Systems Research and Behavioral Science, 14(4), 259-275.

Sushil, S. (2014). Duality of enterprise and stakeholders on flexibility front. Global Journal of Flexible Systems Management, 15(3), $179-180$.

Sutrisno, B. (2020). www.thejakartapost.com. https://www.thejakarta post.com/news/2020/06/29/indonesias-premature-easing-of-rest rictions-risks-prolonged-first-wave-experts.html. Accessed 1 August 2020.

Swim, J. K., Gillis, A. J., \& Hamaty, K. (2020). Gender bending and gender conformity: The social consequences of engaging in feminine and masculine pro-environmental behaviors. Sex Roles, $82,363-385$.

Tan, Y. (2020). www.bbc.com. https://www.bbc.com/news/world53468051. Accessed 29 August 2020. 
Taub, A. (2020). www.nytimes.com. https://www.nytimes.com/ 2020/05/15/world/coronavirus-women-leaders.html. Accessed 26 August 2020.

Thayer, S. E., \& Ray, S. (2006). Online communication preferences across age, gender, and duration of internet use. Cyberpsychology and Behavior, 9(4), 432-440.

Tilley, S., \& Houston, D. (2016). The gender turnaround: Young women now travelling more than young men. Journal of Transport Geography, 54, 349-358.

Timmers, M., Fischer, A. H., \& Manstead, A. S. (1998). Gender differences in motives for regulating emotions. Personality and Social Psychology Bulletin, 24(9), 974-985.

Tribun News (2020). www.newsmaker.tribunnews.com. https://news maker.tribunnews.com/2020/06/10/sosok-reisa-broto-asmoro-dia nggap-buat-tingkat-kecemasan-warga-menurun-ini-reaksi-yunar to-wijaya?page=all. Accessed 02 January 2021.

Turner, T., \& Neimeier, D. (1997). Travel to work and household responsibility: New evidence. Transportation, 24(4), 397-419.

Twenge, J. M. (1999). Mapping gender: The multifactorial approach and the organization of gender-related attributes. Psychology of Women Quarterly, 23, 485-502.

Tybur, J. M., Lieberman, D., \& Griskevicius, V. (2009). Microbes, mating, and morality: Individual differences in three functional domains of disgust. Journal of Personality and Social Psychology, 97(1), 103.

van Leeuwen, F., \& Petersen, M. B. (2018). The behavioral immune system is designed to avoid infected individuals, not outgroup. Evolution and Human Behavior, 39(2), 226-234.

Vantieghem, W., Vermeersch, H., \& Van Houtte, M. (2014). Why gender disappeared from the gap: Re-introducing gender identity theory to educational gender gap research. Social Psychology Education, 17, 357-381.

Warta Ekonomi (2020). www.wartaekonomi.co.id. https://www.warta ekonomi.co.id/read289550/dokter-reisa-jadi-jubir-COVID-19pks-jubir-baiknya-yang-paham-dan-bertanggung-jawab-soalpandemi. Accessed 02 January 2021.

Wang, X., Zhu, X., \& Deng, S. (2020). Female entrepreneurs' gender roles, social capital and willingness to choose external financing. Asian Business Management, 8, 1-26.

Wilson, S. M., Weatherall, A., \& Butler, C. (2004). A rhetorical approach to discussions about health and vegetarianism. Journal of Health Psychology, 9(4), 567-581.

Wittenberg-Cox, A. (2020). www.forbes.com. https://www.forbes. com/sites/avivahwittenbergcox/2020/04/13/what-do-countrieswith-the-best-coronavirus-reponses-have-in-common-womenleaders/\#649e5c833dec. Accessed 26 August 2020.

Wong, Y. J., Levant, R. F., Welsh, M. M., Zaitsoff, A., Garvin, M., King, D., et al. (2015). Masculinity priming: Testing the causal effect of activating subjective masculinity experiences on selfesteem. The Journal of Men's Studies, 23(1), 98-106.

World Health Organization (2020). www.who.int. https://www. who.int/emergencies/diseases/novel-coronavirus-2019/advicefor-public. Accessed 27 August 2020.

Yang, K., \& Grigus, J. S. (2019). Are women more likely than men are to care excessively about maintaingn positive social relationships? A meta-analytic review of the gender difference in sociotropy. Sex Roles, 81, 157-172.

Yang, Y., \& Merrill, E. C. (2017). Cognitive and personality characteristics of masculinity and femininity predict wayfinding competence and strategies of men and women. Sex Roles, $747-758,76$.

Yau, E. K. B., et al. (2020). The behaviour changes in response to COVID-19 pandemic within Malaysia. The Malaysian Journal of Medical Sciences, 30, 45-50.
Publisher's Note Springer Nature remains neutral with regard to jurisdictional claims in published maps and institutional affiliations.

\section{Key Questions}

1. By considering gender as a multidimensional construct, we expect to answer key questions: what gender aspects that influence individual compliance to COVID-19 measures: is it the biological aspect, psychological gender, or gender role?

2. Does feminine characteristic of females promote compliance to COVID-19 measure as assumed by previous studies?

3. Further, our data collection technique utilizing internetbased research is useful to handle social desirability issue since respondents are free to answer the questionnaire in private and in their most convenient time.

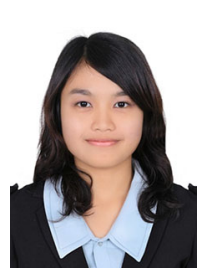

others.
Widya Paramita is a lecturer at the Department of Management, Faculty of Economics and Business, Universitas Gadjah Mada. Her research interests are business ethics, consumer behavior, and service marketing. She has published her works in Journal of Business Ethics, Journal of Business Research, Journal of Retailing and Consumer Services, Marketing Letters, amongst

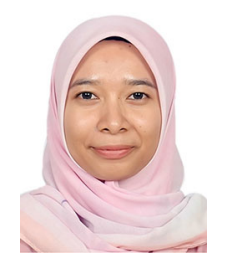

Rokhima Rostiani is a lecturer at the Department of Management, Faculty of Economics and Business, Universitas Gadjah Mada. She is currently enrolled as a PhD student in the Faculty of Economics and Business, Universitas Gadjah Mada. Her research interests are sustainability, entrepreneurship, consumer behaviour, and Islamic marketing.

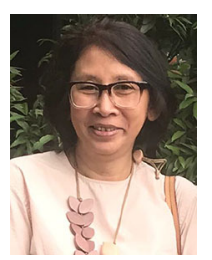

Sari Winahjoe is a lecturer at the Department of Management, Faculty of Economics and Business, Universitas Gadjah Mada. She holds a doctoral degree from Faculty of Economics and Business, Universitas Gadjah Mada. Her research interests are consumer behavior, service marketing, social marketing, and political marketing. 


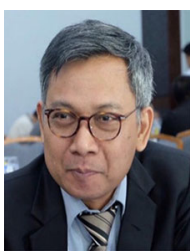

Amin Wibowo is a lecturer at Faculty of Economics and Business, Universitas Gadjah Mada. His research interests are human resource management and strategic management on behavioral perspective. He has published his works in Journal of Management Development, International Journal of Managing Projects in Business, Academy of Strategic Management Journal, International Journal of Learning and Intellectual Capital, amongst others. He also published book entitled Corporate Strategy.

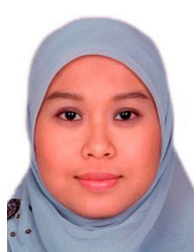

Risa Virgosita is a lecturer at the Department of Management, Faculty of Economics and Business, Universitas Gadjah Mada. She holds a PhD degree from the School of Business, University of Agder, Norway. Her research interests are institutions and entrepreneurship.

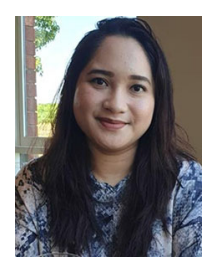

Handini Audita is a lecturer at Faculty of Economics and Business, Universitas Gadjah Mada. wShe is currently undertaking her $\mathrm{PhD}$ degree at RMIT University, Australia. Her research interests are consumer culture, fashion marketing, and social media marketing. 